\title{
Significance of accountability under the new approach to public governance
}

\author{
M. Shamsul Haque
}

\section{Introduction}

The public accountability of public governance ${ }^{1}$ has been a major concern in all societies and civilizations, although there are variations in the criteria, means, and agents of such accountability based on the nature of the polity ranging from traditional to modern, conservative to liberal, capitalist to socialist. Even the connotations of accountability often differ among societies depending on their unique sociohistorical formations, ideological inclinations, and cultural beliefs (see Haque, 1994). The liberal notion of accountability that emerged in advanced capitalist nations could be inconceivable in traditional India, imperial Japan, or communist China. However, during the post-colonial period, most Asian, African, and Latin American countries began to adopt the ideas, principles, and institutions of accountability representing the liberal democratic mode of governance found in advanced capitalist nations (Haque, 1994). In other words, despite the previous cross-national diversity in the modes of public governance and public accountability, the post-colonial period witnessed the convergence, at least in appearance, of these varying patterns of accountability into a common liberaldemocratic model. One of the most crucial features of this liberal-democratic framework is the existence of certain basic mechanisms of accountability such as legislative committee, parliamentary debate, public hearing, ministerial control, ombudsman, and media scrutiny.

Despite the previous critique of these liberal-democratic means of public accountability - especially with regard to their ineffectiveness caused by overcentralized bureaucracy, complex state apparatus, incapable political leaders, and uninformed public (O’Loughlin, 1990) - such democratic means have been quite useful to ensure government accountability in terms of delivering goods and services, addressing public needs and demands, maintaining neutrality and representation, ascertaining citizens' entitlements, and guaranteeing equality and justice. However, in recent years, there has emerged a unique set of challenges to

M. Shamsul Haque is at the Department of Political Science, National University of Singapore. CDU: 65.012.3.

International Review of Administrative Sciences [0020-8523(200012)66:4]

Copyright (C) 2000 IIAS. SAGE Publications (London, Thousand Oaks, CA and New Delhi), Vol. 66 (2000), 599-617; 015342 
the realization of accountability due to the current changes in public governance under the rubric of reinventing or re-engineering government, which is often described as a market-centered, neoliberal approach to governance (Haque, 1998a). The formation of such a neoliberal approach to governance that began with the restructuring of the public sector in advanced capitalist nations such as the USA and the UK, especially under the reform initiatives adopted by Reagan and Thatcher, increasingly became globalized and created a worldwide impact. ${ }^{2}$ During the past two decades, the market-led neoliberal state has largely replaced the welfare state in Western Europe and North America, the socialist state in Eastern Europe, and the developmental state in Asia, Africa, and Latin America (see Haque, 1998a, b).

In the capitalist world, some of the major government initiatives towards such a market-centered governance include Public Service 2000 in Canada, National Performance Review in the USA, Financial Management Initiative and Next Steps in the UK, Renewal of the Public Service in France, Financial Management Improvement Programme in Australia, Modernization Programme for the Public Sector in Denmark, and so on (Haque, 1998d; OECD, 1993, 1995). Such reform initiatives have not only been undertaken in other advanced market economies, they can also be found today in most developing nations (Haque, 1998c; Nunberg, 1997; OECD, 1995; Therkildsen, 1998). One of the central features of these current reforms in these countries has been the application of business principles and practices to the public sector, although such a tendency has been considered problematic by some scholars (Richards, 1996: 21). Although this businesslike approach to governance has been reinforced by internal economic and political forces in advanced capitalist nations, in the case of developing countries, it has been prescribed or imposed largely by international financial agencies.

Under this new global approach based on neoliberal reforms, public governance has undergone significant changes in terms of its objectives, norms, structures, roles, and service recipients. These contemporary changes in governance - toward efficiency, outcome, competition, value-for-money, catalytic role, autonomy, partnership, and customer orientation - have critical implications for its public accountability. According to Romzek (2000: 34), some of these current reforms pose formidable political, managerial, and methodological challenges to accountability. With regard to the seriousness of new challenges to accountability, Barberis (1998: 461) mentions that even if the recently emerged 'new public management' disappears, the accountability gap created by this mode of management will remain. Thus, among the major impacts of contemporary reform initiatives, ${ }^{3}$ the main focus of this article is on the issue of public accountability. It explores how the recent changes in public governance have affected its accountability in terms of the following three dimensions: (1) the standards of accountability (accountability for what), (2) the agents of accountability (accountable to whom), and (3) the means of accountability (how accountability is ensured). 


\section{Emerging concern for the standards of accountability}

A major issue related to public accountability is its contents or standards, which refer to the criteria for which public officials are held accountable to citizens. These standards of accountability have changed considerably under the current mode of public governance due to the restructuring of its objectives and norms that shape such accountability standards. For instance, the traditional objectives and norms of governance (which emerged in advanced democracies and were followed in many developing nations) have been the achievement of socioeconomic progress, law and order, poverty alleviation, employment generation, and public well-being; and the maintenance of values such as impartiality, equality, representation, integrity, fairness, welfare, citizenship, and justice (Haque, 1996; Lewis, 1991). These objectives and norms became the guiding standards of public accountability in most countries. In other words, public servants became accountable for the successful realization of these basic objectives and norms i.e. they were accountable for enhancing human progress, maintaining law and order, resolving poverty and unemployment, providing public welfare, ensuring impartiality and equal treatment, safeguarding citizens' rights, and guaranteeing justice and fairness (Haque, 1998a; Jann, 1997).

But with the recent paradigmatic transition in the mode of public governance, its objectives have shifted to economic growth and productivity, and its normative standards have changed toward efficiency, competition, profit, and valuefor-money, although these standards are largely associated with business management (Clarke and Newman, 1997; Jann, 1997; Kickert, 1997). As Brereton and Temple (1999: 463) mention, it is "uncontroversial to note that there is a consensus that the private sector ethos has "invaded" the public sector'. Among advanced industrial nations, the overwhelming public sector concern for efficiency, economy, competition, and value-for-money can be found in Australia, Canada, France, New Zealand, the UK, and the USA, although such use of business norms may have marginalized or removed traditional public sector values such as honesty, integrity, and neutrality (see Kernaghan, 1997, 2000; OECD, 1995). Many developing countries in Asia, Africa, and Latin America have also moved towards these businesslike objectives and values. ${ }^{4}$ As Konig (1997: 218) suggests, in contemporary public management 'the new diction is the language of the market, of competition, of enterprises, customers and, in a nutshell, of entrepreneurial management'.

These changes in the objectives and values of governance imply corresponding adjustments in the standards of its accountability. Instead of being answerable for social welfare, citizens' rights, poverty eradication, impartiality, fairness, representation, and justice, public governance is increasingly accountable for accelerating economic-growth rate, boosting efficiency and productivity, encouraging competition, maximizing profit, and ascertaining cost effectiveness. Thus, under the current mode of governance, the standards of public accountability have become instrumental in nature, especially in terms of an overemphasis on procedural, economic criteria (e.g. efficiency and productivity) rather than sub- 
stantive public concerns (e.g. equality and representation). It is essential to understand that the accountability of public governance for market-based economic performance does not necessarily imply its accountability for citizens' rights, its accountability for competition and productivity does not guarantee its accountability for representation and equality, and its accountability for higher profit does not connote its accountability for welfare and justice. Thus, the growing primacy of businesslike criteria in realizing the accountability of public governance may, in effect, displace its accountability for the established democratic standards.

The standards of accountability also refer to the expected role or duty of public governance for which it is held accountable. Historically, the post-war period saw the expansion of an active public sector role in delivering goods and services in advanced capitalist nations, enhancing development and nation-building in postcolonial societies, and adopting all-encompassing socioeconomic programmes in socialist countries. Thus, in almost all nation-states, the system of governance became accountable for varying activities and programmes that required its leading role in society. But since the early 1980s, this active, direct, and leading role of public governance has increasingly been replaced with a more passive, indirect, and facilitating role (Peters and Pierre, 1998). This facilitating role of governance comprises various support services to the private sector, maintenance of a conducive atmosphere for market competition, and implementation and monitoring of divestment and contracting out. Under the current ethos of 'new public management', the increasing role of the private sector vis-à-vis the emerging catalytic or facilitating role of public governance can be observed not only in advanced capitalist nations like Australia, Belgium, Canada, France, New Zealand, the UK, and the USA, but also in developing countries such as Malaysia, Korea, Thailand, Singapore, Argentina, Taiwan, and India (see Haque, 2000; Nunberg, 1997).

This shift in the role of governance toward facilitating economic performance through a more extensive leading role of the private sector poses certain challenges to public accountability. For when the public sector plays a direct role in providing goods and services based on concrete socioeconomic programmes and projects, its activities become more tangible and measurable, and thus, easier to scrutinize; whereas its indirect role - to encourage and facilitate the private sector to deliver goods and services — is relatively intangible, immeasurable, and thus, unverifiable. For instance, it is easier to verify the activities of a government housing agency when it is directly involved in building and providing public housing, but it is much more difficult to verify such an agency when it is contracting out the construction and provision of housing to the private sector or transferring the whole sector to private firms and then monitoring and evaluating such market-led housing facilities. Similar conclusions can be drawn with regard to other services such as education and health.

Thus, although it is possible to hold public agencies accountable for tangible performances such as the quantity and quality of services that they directly pro- 
vide, it is not always possible to make them accountable for their intangible performances such as divesting resources, making business deals, and monitoring services contracts. In other words, the current transition in the role of public sector from 'rowing' (direct production and distribution) to 'steering' (indirect monitoring and evaluation) implies a challenge to the realization of its accountability. In addition, apart from business elites, the common citizen may be less interested in making this system of governance, which does not deliver goods and services but facilitates and monitors market forces to perform the task, publicly accountable.

\section{Rising controversy over the agents of accountability}

A major dimension of accountability is the agents or representatives to whom public governance is eventually accountable. In democratic societies, the government is supposed to be accountable to all sections of the population representing various class and group interests. Such a people-centered tradition of accountability evolved with the emergence of a broader civil society, an organized working class, and an increase in the entitlements or rights of common citizens. In the history of capitalist development, the governing institutions went beyond serving the interests of the dominant capitalist class, and became increasingly responsive to the needs of common citizens with an expanding connotation of citizenship (see Marshall, 1994). In socialist countries, on the other hand, the ideological assumption of a classless society required public governance to be collectively accountable to the working class, although in reality it was the ruling class that often exercised monopolistic dominance over the governing institutions. In the developing world, many countries with elected regimes experienced a considerable degree of government accountability for the provision of basic services to various sections of the citizenry. During the post-war period, with the exception of certain authoritarian regimes and totalitarian states, the scope of public accountability expanded in different societies: the state became increasingly accountable to diverse groups and classes of citizens entitled to social services such as education, housing, health, and social security (see Haque, 1999).

However, under the contemporary neoliberal mode of governance, there has been a change in the composition of agents (citizens) who ultimately hold public agencies accountable. This is due to the redefinition of citizens as customers or clients receiving public sector services. Under the current paradigm of 'new public management', this redefinition of citizens as customers represents an accountability challenge, because such a view tends to reduce the social rights associated with collective citizenship to narrow commercial prerogatives of individual customers guided by an exchange relationship (Kaboolian, 1998). In other words, under this reductionist interpretation, public governance is accountable for the effective delivery of its services to customers who can pay, while it may remain indifferent towards low-income citizens who are not in a position to use such services due to their financial incapacity. Despite such adverse implications of this commercial view of citizenship for accountability, a market-driven 
customer orientation in governance has emerged in advanced economies like Australia, Canada, New Zealand, the UK, and the USA, as well as in developing countries such as the Philippines, Malaysia, Singapore, South Africa, Zambia, and Ghana (see Haque, 1999; Roberts, 1999). In this regard, Woodhouse (1997: $46,57)$ mentions that accountability under this consumerist mode of governance is to private customers rather than to the collective public.

Beyond this market-centered redefinition of citizenship, a customer-oriented focus in governance has also been reinforced by the proliferation of user charges (for public goods and services) in countries such as Australia, Canada, Finland, Spain, Germany, the UK, and the USA (OECD, 1998: 1-11). Such user charges are being adopted even in some of the poorest developing countries. ${ }^{5}$ This provision of user charges means that the recipients of public sector services have to pay according to the costs of delivering such services, and it often allows government agencies to determine the amount of charges without being subjected to legislative approval (OECD, 1998; Wilson, 1998). Such a provision is likely to weaken the legal protection of economically underprivileged citizens who often depend on the state for basic services. Thus, the principle of user charges implies that although public governance may be readily accountable to affluent customers, it is not obliged to show accountability to underprivileged citizens who cannot afford user charges and do not qualify as customers.

In other words, the ultimate agents to hold public governance accountable and responsive are increasingly the affluent customers rather than the common citizens. In this regard, Rouban (1995: 57) mentions that the transformation of citizens into customers "implies some kind of distinction between "big" customers (private firms and local political leaders), on the one hand, and "common" users (laymen) who generally cannot afford to deal with public services, on the other'. There are scholars who express concerns that the concept of customer is not appropriate to serve the people by government; that a customer or consumer outlook tends to diminish citizens' rights vis-à-vis the state; and that public accountability requires a system of representation based on much broader view of citizenship rather than the narrow idea of receiving and consuming goods and services (DeLeon, 1997; Peters, 1996; Theobald, 1997).

Beyond these new trends of adopting the concept of customer and provision of user charges, another manifestation of excluding common citizens from the equation of public accountability is the restructuring of the public sector in favor of the affluent business class at the expense of the poorer sections of the population. Under the current market-biased governance, in addition to the windfall gains received by the business elites from their purchase of privatized assets sold at nominal prices and their favorable deals in the contracted-out services (Haque, 1996), the remaining public sector has also been restructured to the disadvantage of underprivileged citizens. Among developed nations, in the recent past, the USA decided to reduce mandatory programs like health care and social security, Germany froze programs supporting the unemployed, France slowed down the growth of health expenditure, Belgium reduced subsidies to social 
security, Canada made cuts in subsidies to regional development programs, Japan retrenched contributions to health care and subsidies to agriculture, and Austria curtailed various welfare programs (OECD, 1997a). Similarly, most Asian, African, and Latin American countries have adopted policies to reduce subsidized social programmes, health services, and education facilities, which have adverse impacts on low-income families (Das, 1998; Haque, 1998b; Mwabu, 1998). As a result of such anti-welfare restructuring of the public sector, the access of common citizens to education and health has diminished in these countries (McGow, 1995; Oxfam International, 1997). In fact, the living standards of low-income citizens have worsened further due to the increasing poverty and unemployment in poorer countries in South Asia, Sub-Saharan Africa, and Latin America (ADB, 1999; Bessis, 1995; Kagami, 1999; McGow, 1995). These trends of declining social programs and services and worsening living standards of low-income citizens, imply the diminishing accountability of public governance to these underprivileged citizens.

Conversely, there has been worldwide expansion of strategies such as public-private partnerships and joint ventures (with local and foreign firms), which demonstrates the increasing accountability of public governance to serve the interests of the business class. In advanced capitalist societies, public-private partnership has often functioned as a mechanism to serve the narrow business interests by bailing out corporations and financing their expansion through credits and loans (Haque, 1996; Petras, 1990). Under the current mode of governance, the frequency of this partnership has multiplied further in Australia, Belgium, Canada, Denmark, Germany, The Netherlands, New Zealand, the UK, and the USA (OECD, 1993, 1995). The governments in many Asian, African, and Latin American countries are also pursuing greater partnership with the business sector, especially with foreign investors (Hamilton, 1989; Haque, 1998a). Under the auspices and influence of various international agencies, such public-private partnerships have proliferated in the major socioeconomic sectors in these developing nations. ${ }^{6}$ Since this mechanism of public-private partnership is often in favor of vested business interests rather than general public concerns, one may conclude that public governance has become more accountable and responsive to the affluent business community rather than to common citizens.

Although some developed and developing countries have recently adopted some sort of citizen's charter ${ }^{7}$ to enhance the responsiveness and accountability of the public service to its clients or customers, the critics are quite skeptical about it. It has been mentioned that such a charter has been adopted without public participation; that it empowers consumers rather than citizens; and that it may guarantee certain rights to individual customers but not to citizens (see Hunt, 1998: 44; Peters, 1997: 265). In this regard, there seems to be an inherent contradiction within the overall reform agenda associated with public governance. On the one hand, the citizen's charter may empower the affluent customers or users of services to make public agencies responsive to their choices and expectations; on the other hand, the very principles of customer choices and user charges 
may diminish the power and opportunity of low-income citizens, who cannot become clients due to financial hardship, to hold such agencies accountable. Thus, in the prevailing context of public governance, public accountability, in effect, has become a more fragmented, class-biased accountability. This controversy over the ultimate agents to whom public governance is accountable indicates the increasing significance of rethinking public accountability in the current age.

\section{Growing challenge to the means of accountability}

The question of public accountability has also become more significant due to the growing challenge to various means of accountability posed by recent changes in governance. The major means of accountability that are traditionally practiced in western democracies and followed in many developing countries, include the following:

1. external-formal mechanisms, including legislative instruments (legislative committees and parliamentary questions), executive means (controls exercised by political executives over public agencies), and judicial or quasi-judicial processes (administrative courts and ombudsmen);

2. external-informal mechanisms, such as public hearings, interest groups, opinion polls, and media scrutiny;

3. internal-formal means, including officials rules, codes of conducts, official hierarchies, and performance reviews; and

4. internal-informal mechanisms, such as organizational culture, professional ethics, and peer pressure (DeLeon, 1998; Haque, 1994; Heeks, 1998).

The viability of these established and widely practiced means of public accountability is affected by the emerging neoliberal mode of governance, which has brought new sets of institutions, structures, and norms, and expanded the scope for administrative politicization, managerial autonomy, and public-private partnership mentioned earlier.

First, one of the basic prerequisites for public accountability in democracies is the political neutrality of career public servants, which has come under challenge due to the growing power of ministers or political executives to exert influence on the public service. In this regard, it has been pointed out by Rhodes (1997: 46) that in countries such as the UK, this is an era of macho-ministers in terms of expanded ministerial power to make decisions related to the appointment, dismissal, and retirement of top civil servants. These decisions are increasingly based on the political considerations and personal preferences of ministers. Similarly, in France, under the recent reforms in governance, the rise of ministerial power to politicize the civil service 'has contributed to blurring the professional lines traditionally drawn between politicians and civil servants' (Rouban, 1995: 50). The politicization of civil servants by ministers — which violates the principle of political neutrality, and thus public accountability, of public employees - has become much easier due to the recent policy to 
eliminate permanent tenure of senior public servants and introduce temporary contract-based appointments. ${ }^{8}$

Such a policy makes these public servants more vulnerable to political executives who now exercise control over their job contracts and careers. For example, in New Zealand, the tenured heads of government agencies have been replaced with the so-called chief executives appointed for five years based on individual contracts; in the UK, the chief executives of departmental agencies created under the Next Steps program, are appointed on fixed-term contracts; and a similar pattern is being followed in Norway (Hood, 1995: 109; Scott, 1994: 174). These changes are not conducive to accountability because the means of accountability, such as ministerial control or supervision over public servants, is meaningful only when public servants are politically neutral, and when they enjoy such immunity from political influence due to their merit-based selection and job permanence. When senior public servants are already politicized - especially because their appointments are on short-term contracts decided by ministers as the political heads - the ministerial control as a means of accountability may not only make these public servants extremely loyal to their respective ministers while ignoring their accountability to the general public, it may also expand the power of ministers to the extent that they themselves become less accountable to the public.

Second, the structural and procedural autonomy of public management prescribed under the current governance system may also affect the existing means of accountability. Nevertheless, managerial autonomy has been introduced in countries such as New Zealand, Canada, France, Denmark, Finland, The Netherlands, Spain, Switzerland, and the UK. These countries have disaggregated and corporatized various ministries and departments into many autonomous entities - often known as executive agencies, autonomous agencies, free agencies, or special operating agencies - each of which deals with a limited number of services and enjoys considerable financial and personnel autonomy (see OECD, 1993, 1997a). Under this arrangement, the central government in most of these countries has largely become a purchaser of services for its citizens or customers from these autonomous agencies that behave like private corporations in terms of the extent of their managerial autonomy (Peters, 1996; Roberts, 1999). In the developing world, similar managerial autonomy in public governance is being emphasized in the Philippines, Malaysia, Singapore, South Korea, Thailand, Botswana, Ghana, South Africa, and Uganda (Dia, 1994; Haque, 1998c; World Bank, 1995).

This newly emerging autonomy of public agencies poses a challenge to the democratic means of public accountability, because it reduces the avenues for elected political representatives to scrutinize the activities of these agencies, and it diminishes the scope of legislative debates over programs undertaken by such agencies that are run like private corporations with maximum operational autonomy. In fact, many political leaders are not used to such an autonomous mode of public governance, and they do not have the experience and resources to 
evaluate and scrutinize these newly created agencies. In cases such as New Zealand, France, and the UK, despite the relative inexperience and incapacity of ministers to oversee autonomous public agencies, they may still prefer such a system, because they can use the 'smoke-screen of managerial autonomy' to take credit for good performance and blame managers or chief executives for any negative performance of these autonomous agencies (Irwin, 1996: 15; Rhodes, 1997: 55; Wright, 1997: 11). In other words, the accountability of these new executive agencies is ineffective not only due to the prescribed autonomy of these agencies from controls exercised by legislators and their unfamiliarity with such new agencies, but also due to the expanded avenue for ministers to avoid responsibilities and deflect blame onto public managers. ${ }^{9}$

On the other hand, in the absence of adequate control and scrutiny, the newly acquired financial, personnel, and managerial autonomy may expand the opportunity of chief executives of autonomous agencies for abuse and corruption. ${ }^{10}$ In relation to the situation in Australia, Canada, New Zealand, the UK, and the USA, there are already growing concerns among scholars that increased managerial autonomy in public governance may expand the avenues for using public office for private gains; that decentralized budgeting poses a challenge to financial accountability; and that the 'businessing' of public service may have increased the abuse of official power (Kernaghan, 1992; Peters, 1996; Theobald, 1997). Critics also mention that excessive managerial freedom may encourage public employees to overlook laws and rules and weaken administrative scrutiny by superiors; and that the process of corporatization and outsourcing is likely to make the means of accountability such as auditing and accounting more difficult (Arnold et al., 1998; DeLeon, 1997). These points indicate, in short, that the current structural changes in governance based on unprecedented managerial autonomy pose a serious challenge to the traditional means of public accountability.

Third, there have been major changes in the criteria to evaluate program and performance in the public sector as a means to ensure its public accountability. More specifically, under 'new public management', many countries have shifted from process-oriented to result-oriented performance with an increasing focus on outcomes rather than inputs - public agencies and employees are supposed to be accountable for policy outcomes rather than policy processes. This trend toward result-oriented or outcome-driven mode of governance has emerged not only in advanced industrial nations, but also in developing countries such as Brazil, Mexico, Malaysia, Botswana, Colombia, Uganda, Costa Rica, Jamaica, Singapore, and the Philippines (Haque, 1998c, 2000; World Bank, 1997). In cases such as New Zealand, this result-oriented governance involves the delineation of major result areas, expenditure plans, investments and profits, and eventually, an outcome-based budget (Irwin, 1996). Such outcome-based budgeting is becoming a common practice in countries that have restructured the public sector into autonomous agencies mentioned earlier.

As far as the issue of accountability is concerned, this result-oriented mode of 
governance is likely to render the existing means of accountability ineffective. There are several reasons for this. First, it is difficult to put such an outcomebased system under legislative scrutiny or debate due to the qualitative and controversial nature of public-sector outcomes such as environmental security, poverty alleviation, and community development. In addition a major part of each of these outcomes could be attributed to external factors outside the jurisdiction of government agencies (Irwin, 1996). Finally, due to an overemphasis on outcomes or results, the chief executives of autonomous agencies could be so obsessed with results (e.g. increased level of employment) that they might adopt undesirable means (e.g. expansion of the toxic chemical industry for more jobs) just to produce better results. In other words, the result-oriented system tends to increase the focus on 'what' is being achieved by public agencies, but it may overlook the procedural question of 'how' such achievements are made. This implies the diminishing relevance of such means of public accountability as internal control and supervision over various inputs and processes in the public sector.

Finally, the expansion of public-private partnerships and exchanges under the current mode of governance poses a threat to certain means of accountability, because such partnerships and exchanges are less amenable to normal legislative scrutiny and ministerial supervision. More specifically, it is not always possible to monitor the mode of interaction and negotiation between government executives and business managers, and to decipher whether the joint ventures or business deals are made in favor of private firms at the expense of public interest. For instance, there is a growing public concern in the US with regard to government contracts with private firms, because these contracts often involve extra-legal tactics and expand opportunities for kickbacks (Frederickson and Frederickson, 1995; Rubin, 1993). In the case of Malaysia, the question has been raised of whether the recent expansion of partnership and exchange between the public and business sectors may have compromised the impartiality and accountability of the public service (Sarji, 1996: 117). It should be emphasized that even when public agencies are placed under intensive public scrutiny, their private-sector partners are not under the scutiny of legislative investigation, ministerial supervision, and administrative control, especially when such business partners are foreign firms or investors. ${ }^{11}$ Thus, the current proliferation of public-private partnership and exchange represents a challenge to various legislative and executive means of public accountability.

\section{Alternatives and concluding remarks}

In this article, it has been emphasized that public governance in most countries has recently undergone considerable change in terms of its objectives, norms, roles, structures, and service recipients, which have serious implications for its public accountability. In this regard, this article explored how these contemporary changes in governance adversely affected the contents, agents, and means of its accountability. These critical observations on the challenges to public accountability under the current businesslike approach to governance imply the increas- 
ing significance of the issue in this age of neoliberal reforms. This last section of the article examines certain alternatives to address these emerging challenges and concerns related to public accountability.

First, with regard to the standards of accountability, it is necessary to realize that the objectives, norms, and roles of public governance are different from those of the private sector. Although economic efficiency, economy, and competition are important as criteria of accountability, what makes public governance truly public and distinguishes it from private-sector management is its accountability for a unique set of public missions and norms such as representation, equality, impartiality, integrity, justice, and citizenship. In this regard, Lewis (1991: 7) mentions that the private sector has standards that are different from those in the public sector, and this distinction has been overlooked in the process of embracing businesslike entrepreneurship by the US government. In the case of the UK, Rhodes (1997: 55) observes that the current managerialism and its standards like economy, efficiency, and effectiveness, have eroded the traditional values of government, and pose a challenge to the culture of public governance. It needs to be understood that public governance can afford to be less efficient, but it cannot overlook issues such as racial discrimination, social injustice, and violation of citizens' rights. As Kickert (1997: 34) suggests, in a democracy, 'a sacrifice in the degree of rationality and efficiency must be made.... Without denying whatsoever the great importance of effectiveness and efficiency in the public sector, other norms and values play a role as well; values such as liberty, legality, legitimacy, equity and social justice.' This basic normative dimension must be taken into consideration by policy-makers and reformers in articulating the standards if public governance is to be held accountable.

Second, with regard to the ultimate agents holding public governance accountable, it is necessary to ensure such accountability not just to the affluent users or customers of public sector services but to all groups and classes of citizens, including low-income households. In this regard, the top policy-makers need to re-examine the current tendency to view citizens as customers because, as discussed in this article, the concept of customer used in the marketplace is devoid of entitlements or rights associated with citizenship. It has been previously suggested that this exclusion or marginalization of citizenship rights, caused by the use of the customer principle, implies that public governance is less responsive and accountable to underprivileged citizens who cannot financially qualify as customers or clients. This erosion of citizens' entitlements also means that the level of public confidence in governance may diminish, especially among lowincome citizens. ${ }^{12}$ This diminishing confidence represents a reminder to policymakers that public governance must be made responsive and held accountable to common citizens in relation to their socioeconomic needs and concerns. Although some countries have introduced various forms of public consultation to address this declining public trust in governance ${ }^{13}$ more needs to be done in terms of restoring or expanding citizens' rights to basic public services such as education, health, and housing. 
Finally, in order to overcome the aforementioned challenges to various means of accountability, it is necessary to reinforce the political neutrality of public service, which has come under threat due to increasing ministerial influence and intervention in public personnel matters. According to Theobald (1997), in fact, the very intention behind the current businesslike reforms in public governance has been political — in the context of continuing socioeconomic declines, reform-minded political leaders often had a vested interest in deflecting public attention and criticism away from their own failures by targeting the shortcomings of the public service. However, these neoliberal political reformers must pay attention to the fact that such a political tactic can merely be a stopgap measure, and as mentioned earlier, this measure has failed to enhance public confidence in government institutions in most cases (see Haque, 2000). More importantly, the motive to politicize public sector reforms goes against the very objectives of these reforms such as efficiency and competition, which require political neutrality and impartiality. In order to minimize politicization and increase political neutrality, it is necessary to reduce the job insecurity of public servants, so that they are less vulnerable to their political heads determining their careers based on vested political interest or agenda. More specifically, it may be necessary to rethink the emerging trend of short-term, contract-based appointments offered by ministers or political executives to senior public servants and to restore merit-based appointments and permanent tenure in order to enhance the civil service's immunity to political influence. This policy reversal toward a more meritocratic and permanent public service may minimize ministerial intervention, reduce the politicization of public employees, and ensure that senior public servants are concerned with public accountability rather than political loyalty.

It is also necessary to critically examine the recent proliferation of autonomous agencies, result-oriented budget, and public-private partnerships. As explained in this article, the financial and managerial autonomy of these public agencies may render various traditional means of accountability ineffective. Such a problem needs to be addressed by establishing greater control and closer supervision over financial and managerial matters and public-private dealings. More specifically, it may be necessary to introduce the following:

1. new legislative mechanisms to have closer scrutiny over budgetary and personnel matters related to autonomous agencies;

2. comprehensive rules and institutions to oversee public-private ventures and transactions;

3. legal provision requiring ministries and agencies to ensure greater transparency and public access to relevant information;

4. guarantee of press freedom to report official corruption and mismanagement;

5. government rules requiring the declaration of personal incomes and assets by all public officials (both elected and appointed); ${ }^{14}$ 
6. increase in the authority and capacity of anti-corruption agencies; and

7. frequent use of opinion surveys to decipher citizens' reaction to any reform introduced in public governance.

The last measure related to people's opinion is crucial, because, in most countries, the businesslike neoliberal reforms in governance have recently been introduced through presidential decrees without care for public reaction; and in many cases, these reforms are largely characterized by a top-down approach, an authoritarian political style, the dominance of market-friendly political parties, and the exclusion of opposition voices (see Pereira et al., 1993: 9). These features of neoliberal reforms, in fact, are incompatible with the basic democratic institutions - including people's participation, legislative debate, public opinion, and alternative viewpoint - which are essential prerequisites for ensuring government's accountability to the public. In a genuine democracy, these institutions must prevail to guarantee such public accountability that is increasingly under challenge in this age of neoliberal approach to governance.

\section{Notes}

1. In general, public governance encompasses the institutions and functions of the state, underscores the rule of law, involves interaction between the state and civil society, implies government capacity to conduct policies for economic performance and welfare, and underlines the management of economic and social resources. On the other hand, the public accountability of such a governance system connotes the answerability of public officials to the public for their actions and inactions for which they are subject to both external or internal sanctions (Haque, 1994; Oakerson, 1989; Romzek, 2000).

2. The major factors behind the globalization of neoliberal governance have been the loan conditionalities imposed by international and regional organizations - including the World Bank, the IMF, the USAID, the Commonwealth Secretariat, and the OECD - on developing countries and transitional economies to adopt market-led policies and reforms such as privatization, deregulation, liberalization, and corporatization (Haque, 1998b; Kickert, 1997; Llewellyn and Varghese, 1997). However, there are cross-national variations in such reforms in terms of scope, form, and intensity. For instance, these marketdriven reforms have been more serious and intensive in the USA, the UK, New Zealand, Australia, and Canada than countries such as Germany, Denmark, and The Netherlands (Llewellyn and Varghese, 1997; Roberts, 1999). But the point here is that irrespective of such cross-national differences, within each of these countries, the common trend has been the transition towards a neoliberal mode of public governance.

3. According to Wright (1997: 9-12), there are inherent contradictions within the current reforms in governance: for example, the most radical reforms are being adopted in countries where they are least needed; the top bureaucrats, although demonized as inefficient by political reformers, have played crucial roles in these reforms; the rationale of such reforms as efficiency and economy is difficult to measure in a public sector replete with complex externalities and linkages; and the primary goal of these reforms - to reduce the role of the state - itself requires a strong state to implement such a goal.

4. For instance, growth, efficiency, productivity, performance, effectiveness, and partnership have gained more prominence in contemporary public governance in Asian countries such as Malaysia, Brunei, Singapore, Hong Kong, Thailand, and the Philippines (Arnold et al., 1998; Halligan and Turner, 1995; Haque, 1998c; Salleh, 1992). Similarly, in South Africa, the recent public sector reforms have been guided by these market-based business principles (see Muller et al., 1997). 
5. In Africa, for example, user charges are being introduced in Uganda, Zimbabwe, Ghana, Egypt, Tanzania, Mali, Rwanda, Sudan, and Nigeria (Mwabu, 1998).

6. In Asia, public-private partnership has expanded in Malaysia, Thailand, the Philippines, Indonesia, Vietnam, South Korea, Taiwan, India, Pakistan, and Bangladesh; and in Africa, the examples include Ghana, Zambia, Zimbabwe, Malawi, Senegal, Mozambique, and Uganda (see Haque, 1998a; World Bank, 1996).

7. The major examples include the following: Public Services Users' Charter in Belgium, Public Services Charter in France, Citizen's Charter in the UK and Italy, Quality Service Initiative in Canada, Quality Charter in Public Services in Portugal, Quality Observatory in Spain, Customer Service Standards in the USA, Clients Charter in Malaysia, and Client Surveys in India, Nicaragua, and Tanzania (Mussari, 1998; OECD, 1995; World Bank, 1997).

8. The permanent careers of senior public servants have been replaced by fixed-term contracts in countries such as Austria, Australia, Denmark, Finland, France, Germany, Ireland, New Zealand, Norway, Sweden, Switzerland, and the UK (OECD, 1997b).

9. As Pierre (1995: 3) mentions, there is a 'general desire among elected politicians to increase their influence over bureaucracy while at the same time avoiding responsibility for the bureaucracy's action'.

10. It has been pointed out that increasingly, fraud and abuse have come to plague the public sector in countries such as the USA and New Zealand (Gregory, 1999: 68; Kettl, 1998: 30).

11. In recent years, there have been significant increases in foreign investment, joint venture (between government agencies and foreign companies), and foreign ownership in developing countries (Cook and Kirkpatrick, 1995: 14-15).

12. From some recent surveys and findings, it can be observed that people's confidence in various public institutions has declined in countries such as Australia, Belgium, Brazil, Bulgaria, Canada, Chile, Italy, Latvia, Lithuania, Mexico, Norway, the Philippines, Russia, South Korea, the UK, and the USA (Haque, 2000; Rotella, 1997).

13. In response to this decline in public trust, countries such as Finland, Portugal, Sweden, Switzerland, and the USA have introduced constitutional or legal rights for public consultation, and adopted a more open participatory decision-making process (Keating, 1998).

14. For senior public officials, the written declaration of property, shares, business relationships, and directorships in private corporations is required in countries such as Australia, Canada, Finland, Germany, Ireland, Mexico, Portugal, Sweden, the UK, and the USA (OECD, 1997b). However, the USA is the only country where such declaration is made fully public. This practice should be followed by other countries, particularly because of the growing number of public-private partnerships, the blurring of the boundary between public and private interests, and the increasing scope for using autonomous public agencies for personal gains.

\section{References}

ADB (African Development Bank) (1999) African Development Report 1999. London: Oxford University Press.

Arnold, Gayle, Llewellyn, Joanne and Mao, Qiumeng (1998) 'International Trends in Public Administration-Notes', Canberra Bulletin of Public Administration, No. 88 (May).

Barberis, Peter (1998) 'The New Public Management and a New Accountability', Public Administration 76(3): 451-70.

Bessis, Sophie (1995) From Social Exclusion to Social Cohesion: A Policy Agenda. Policy Paper No. 2, Management of Social Transformation (MOST). Paris: UNESCO. 
Brereton, Michael and Temple, Michael (1999) 'The New Public Service Ethos: An Ethical Environment for Governance', Public Administration 77(3): 455-74.

Clarke, John and Newman, Janet (1997) The Managerial State: Power, Politics and Ideology in the Remaking of Social Welfare. London: Sage.

Cook, P. and Kirkpatrick, C. (1995) 'Privatization Policy and Performance', in P. Cook and C. Kirkpatrick (eds) Privatization Policy and Performance: International Perspectives, pp. 3-27. London: Prentice Hall/Harvester Wheatsheaf.

Das, S.K. (1998) Civil Service Reform and Structural Adjustment. Delhi: Oxford University Press.

DeLeon, Linda (1997) ‘Administrative Reform and Democratic Accountability’, in Walter J.M. Kickert (ed.) Public Management and Administrative Reform in Western Europe, pp. 237-52. Cheltenham, UK: Edward Elgar.

DeLeon, Linda (1998) 'Accountability in a 'Reinvented' Government', Public Administration 76(3): 539-58.

Dia, Mamadou (1994) 'Civil Service Reform: The African Experience', in Shahid Amjad Chaudhry, Gary James Reid and Waleed Haider Malik (eds) Civil Service Reform in Latin America and the Caribbean, pp. 18-21. Washington, DC: World Bank.

Frederickson, George and Frederickson, David G. (1995) 'Public Perceptions of Ethics in Government', Annals of the American Academy of Political and Social Science 537 (Jan.): 163-72.

Gregory, Robert J. (1999) 'Social Capital Theory and Administrative Reform: Maintaining Ethical Theory in Public Service', Public Administration Review 59(1): 63-75.

Halligan, John and Turner, Mark (1995) Profiles of Government Administration in Asia. Canberra: Australian Government Publishing Service.

Hamilton, C. (1989) 'The Irrelevance of Economic Liberalization in the Third World', World Development 17(10): 1523-30.

Haque, M. Shamsul (1994) 'The Emerging Challenges to Bureaucratic Accountability: A Critical Perspective', in Ali Farazmand (ed.) Handbook of Bureaucracy, pp. 265-86. New York: Marcel Dekker.

Haque, M. Shamsul (1996) 'Public Service Under Challenge in the Age of Privatization', Governance 9(2): 186-216.

Haque, M. Shamsul (1998a) 'Paradox of Bureaucratic Accountability in Developing Nations Under a Promarket State', International Political Science Review 19(4): 357-72.

Haque, M. Shamsul (1998b) 'Impacts of Globalization on the Role of the State and Bureaucracy in Asia', Administrative Theory \& Praxis 20(4): 439-51.

Haque, M. Shamsul (1998c) 'New Directions in Bureaucratic Change in Southeast Asia: Selected Experiences', Journal of Political and Military Sociology 26(1): 96-114.

Haque, M. Shamsul (1998d) 'Legitimation Crisis: A Challenge for Public Service in the Next Century', International Review of Administrative Sciences 64(1): 13-26.

Haque, M. Shamsul (1999) 'Relationship Between Citizenship and Public Administration: A Reconfiguration', International Review of Administrative Sciences 65(3): 309-25.

Haque, M. Shamsul (2001) 'The Diminishing Publicness of Public Service Under the Current Mode of Governance', Public Administration Review 61 (forthcoming).

Heeks, Richard (1998) Information Systems and Public Sector Accountability. Information Systems for Public Sector Management Working Paper No. 1. Manchester: Institute for Development Policy and Management, University of Manchester.

Hood, Christopher (1995) 'Deprivileging the UK Civil Service in the 1980s: Dream or Reality?', in Harold W. Stanley and Richard G. Niemi (eds) Vital Statistics on American Politics, 5th edn, pp. 92-117. Washington, DC: Congressional Quarterly.

Hunt, Michael (1998) 'Citizenship and Freedom of Information', in Michael Hunt and 
Barry J. O'Toole (eds) Reform, Ethics and Leadership in Public Service, pp. 41-54. Aldershot: Ashgate.

Irwin, Tim (1996) 'An Analysis of New Zealand's New System of Public-Sector Management', in OECD (ed.) Performance Management in Government: Contemporary Illustrations, Public Management Occasional Papers No. 9. Paris: OECD.

Jann, Werner (1997) 'Public Management Reform in Germany: A Revolution without a Theory?', in Walter J.M. Kickert (ed.) Public Management and Administrative Reform in Western Europe, pp. 83-102. Cheltenham, UK: Edward Elgar.

Kaboolian, Linda (1998) 'The New Public Management: Challenging the Boundaries of the Management vs. Administration Debate', Public Administration Review 58(3).

Kagami, Mitsuhiro (1999) 'Privatization and Deregulation: The Case of Japan', in Mitsuhiro Kagami and Masatsugu Tsuji (eds) Privatization, Deregulation and Institutional Framework, pp. 1-21. Tokyo: Institute of Developing Economies.

Keating, Michael (1998) Public Management Reform and Economic and Social Development. Paris: OECD.

Kernaghan, Kenneth (1992) 'Empowerment and Public Administration: Revolutionary Advance or Passing Fancy?', Canadian Public Administration 35(2): 194-214.

Kernaghan, Kenneth (1997) 'Towards a Public-Service Code of Conduct — and Beyond', Canadian Public Administration 40(1): 40-54.

Kernaghan, Kenneth (2000) 'The Post-Bureaucratic Organization and Public Service Values', International Review of Administrative Sciences 66(1): 91-104.

Kettl, Donald F. (1998) Reinventing Government: A Fifth-Year Report Card. Washington, DC: The Brookings Institution.

Kickert, Walter (1997) 'Public Management in the United States and Europe', in Walter J.M. Kickert (ed.) Public Management and Administrative Reform in Western Europe, pp. 15-39. Cheltenham, UK: Edward Elgar.

Konig, Klaus (1997) 'Entrepreneurial Management or Executive Administration: The Perspective of Classical Public Administration', in Walter J.M. Kickert (ed.) Public Management and Administrative Reform in Western Europe, pp. 217-36. Cheltenham, UK: Edward Elgar.

Lewis, Carol W. (1991) The Ethics Challenge in Public Service. San Francisco, CA: Jossey-Bass.

Llewellyn, Joanne and Varghese, Margaret (1997) 'International Trends in Public Administration - Notes', Canberra Bulletin of Public Administration No. 86 (Dec.).

Marshall, T.H. (1994) 'Citizenship and Social Class', in Bryan S. Turner and Peter Hamilton (eds) Citizenship: Critical Concepts, Vol. II, pp. 5-43. London: Routledge.

McGow, Lisa (1995) The Ignored Cost of Adjustment: Women Under SAPs in Africa. Washington, DC: The Development GAP.

Muller, J.J. et al. (1997) 'Civil Service Systems in Comparative Perspective: South Africa - A Country Study', Paper presented at the Conference on Civil Service Systems in Comparative Perspective, School of Public and Environmental Affairs, Indiana University, Indiana, 5-8 April.

Mussari, Riccardo (1998) 'The Citizen's Charter: Opportunity for NPM Implementation in Italian Health Services', Paper presented at International Public Management Network Conference on Democratic Accountability and the New Public Management, Atkinson Graduate School of Management, Willamette University, Oregon, 28-30 June.

Mwabu, Germano (1998) Health Development in Africa. Economic Research Papers No. 38. Abidjan, Cote d'Ivoire: The African Development Bank.

Nunberg, Barbara (1997) 'Leading the Horse to Water: Transnational Inducements to Administrative Reform', Paper presented at the Conference on Civil Service Systems in Comparative Perspective, School of Public and Environmental Affairs, Indiana University, Indiana, 5-8 April. 
Oakerson, Ronald J. (1989) 'Governance Structures for Enhancing Accountability and Responsiveness', in James L. Perry (ed.) Handbook of Public Administration, pp. 114-30. San Francisco, CA: Jossey-Bass.

OECD (1993) Public Management Development Survey 1993. Paris: OECD.

OECD (1995) Public Management Developments: Update 1995. Paris: OECD.

OECD (1997a) Issues and Developments in Public Management: Survey 1996-1997. Paris: OECD.

OECD (1997b) Managing the Senior Public Service: A Survey of OECD Countries. Paris: OECD.

OECD (1998) 'Best Practice Guidelines for User Charging for Government Services', in OECD (ed.) User Charging for Government Services: Best Practice Guidelines and Case Studies, Occasional Papers No. 22. Paris: OECD.

O'Loughlin, Michael G. (1990) 'What is Bureaucratic Accountability and How Can We Measure It?', Administration and Society 22(3): 275-302.

Oxfam International (1997) Growth with Equity: An Agenda for Poverty Reduction. Oxford, UK: Oxfam International.

Pereira, L.C.B., Maravall, J.M. and Przeworski, A. (1993) 'Introduction', in Luiz Carlos Bresser Pereira, Jose Maria Maravall and Adam Przeworski (eds) Economic Reforms in New Democracies: A Social Democratic Approach, pp. 1-14. New York: Cambridge University Press.

Peters, B. Guy (1996) The Future of Governing: Four Emerging Models. Kansas: University Press of Kansas.

Peters, B. Guy (1997) 'A North American Perspective on Administrative Modernization in Europe', in Walter J.M. Kickert (ed.) Public Management and Administrative Reform in Western Europe, pp. 255-70. Cheltenham, UK: Edward Elgar.

Peters, B. Guy and Pierre, John (1998) 'Governance without Government? Rethinking Public Administration', Journal of Public Administration, Research \& Theory 8 (Apr.): 223-43.

Petras, James (1990) 'The World Market: Battleground for the 1990s', Journal of Contemporary Asia 20(2): 145-76.

Pierre, Jon (1995) 'Comparative Public Administration: The State of the Art', in Harold W. Stanley and Richard G. Niemi (eds) Vital Statistics on American Politics, 5th edn, pp. 1-17. Washington, DC: Congressional Quarterly.

Rhodes, Rod (1997) 'Reinventing Whitehall, 1979-1995', in Walter J.M. Kickert (ed.) Public Management and Administrative Reform in Western Europe, pp. 43-60. Cheltenham, UK: Edward Elgar.

Richards, Greg (1996) 'Businesslike Government: The Ultimate Oxymoron?', Optimum: The Journal of Public Sector Management 27(1): 21-5.

Roberts, Alasdair (1999) 'REGO (Reinventing Government) Around the World', Government Executive (Jan.). (www.govtexec.com/features/0199/019985.htm)

Romzek, Barbara S. (2000) 'Dynamics of Public Accountability in an Era of Reform', International Review of Administrative Sciences 66(1): 21-44.

Rotella, Sebastian (1997) 'In Latin America, Politics Become Eclectic', Los Angeles Times, 19 December, p. A-5.

Rouban, Luc (1995) 'Public Administration at the Crossroads: The End of the French Specificity?', in Harold W. Stanley and Richard G. Niemi (eds) Vital Statistics on American Politics, 5th edn, pp. 39-63. Washington, DC: Congressional Quarterly.

Rubin, Irene S. (1993) 'The Politics of Expenditures: Managing Competition, Accountability, and Acceptability', in Peter Kobrak (ed.) The Political Environment of Public Management, pp. 221-53. New York: Harper Collins.

Salleh, Sirajuddin H. (1992) 'A Glance at the Civil Service Reforms in the Asean Countries', in Sirajuddin H. Salleh (ed.) Civil Service in the South Asian Region: 
Challenges and Prospects of the Year 2000, pp. 27-53. Kuala Lumpur: Asian and Pacific Development Centre.

Sarji, Ahmad (1996) Civil Service Reforms: Towards Malaysia's Vision 2020. Selangor, Malaysia: Pelanduk Publications Sdn. Bhd.

Scott, Graham (1994) 'Strengthening Government Capacity to Manage Human Resources: The New Zealand Experience', in Shahid Amjad Chaudhry, Gary James Reid and Waleed Haider Malik (eds) Civil Service Reform in Latin America and the Caribbean, pp. 172-9. Washington, DC: The World Bank.

Theobald, Robin (1997) 'Enhancing Public Service Ethics: More Culture, Less Bureaucracy?', Administration \& Society 29(4): 490-504.

Therkildsen, Ole (1998) 'Public Sector Reform in Eastern and Southern Africa', Researching Development at CDR Copenhagen, September.

Wilson, Gord (1998) 'User Charging for Air Traffic Control Services: Nav Canada', in OECD (ed.) User Charging for Government Services: Best Practice Guidelines and Case Studies, Occasional Papers No. 22. Paris: OECD.

Woodhouse, Diana (1997) In Pursuit of Good Administration. Oxford, UK: Oxford University Press.

World Bank (1995) Bureaucrats in Business: The Economics and Politics of Government Ownership. New York: Oxford University Press.

World Bank (1996) World Bank Annual Report 1996. Washington, DC: International Bank for Reconstruction and Development.

World Bank (1997) World Development Report 1997: The State in a Changing World. New York: Oxford University Press.

Wright, Vincent (1997) 'The Paradoxes of Administrative Reform', in Walter J.M. Kickert (ed.) Public Management and Administrative Reform in Western Europe, pp. 7-13. Cheltenham, UK: Edward Elgar. 